\title{
ENCOURAGING PARTICIPATIVE APPROACH IN DOCTORAL SUPERVISION: MODERN DISCOURSE REVIEW
}

\author{
Boychuk P. M., Fast O. L., Martyniuk A. P.
}

\section{INTRODUCTION}

With the development of a more knowledge-based economy, the role of universities continues to evolve. They are seen by governments as key actors supporting industrial competitiveness and improving the quality of life. Next to education and research, services to economy and society and exploitation of research results are seen as the «third mission» of universities. At the same time, in addition to specific activities linked to improving existing and developing new products, processes and services, addressing grand societal challenges call for a supply of research talent able to develop interdisciplinary solutions that also take into account the economic, environmental and social impact of technologies. This is a requirement for all doctoral researchers, whether they pursue a career in academia or in the wide range of the non-academic sector. The development of researchers to take their place in driving innovation in Europe will depend on their having a comprehensive range of professional development opportunities to develop themselves as «creative critical autonomous intellectual risk-takers» ${ }^{1}$.

There have been significant changes in doctoral education in Europe in recent years. Three drivers have led many universities to introduce change: the first is the recognition that many doctoral graduates seek employment outside the academy and their high level skills are much sought after, secondly that the model of the lone scholar is no longer appropriate, and thirdly that heavy reliance on a single $\mathrm{PhD}$ supervisor guiding the development of the $\mathrm{PhD}$ candidate is not robust.

This has led to the development of structured PhDs where 1) doctoral programmes bring together cohorts of candidates and include elements of professional development training, regular involvement in activities of research groups such as seminars and journal clubs, teaching, sometimes

\footnotetext{
${ }^{1}$ European Commission: Europe 2020 - A European Strategy for smart, sustainable and inclusive growth. European Commission, COM (3.3. 2010) (2010).
} 
also technical courses, and where 2) institutions have central or overarching administrative structures such as one or more graduate or doctoral schools to support doctoral programmes. These elements are an integral, although usually only a relatively small part of the total programme allowing $\mathrm{PhD}$ candidates to concentrate on their research towards the doctorate, firmly anchored in a rich research environment with access to colleagues outside of their supervisory team to interact with. Candidates are overseen by a supervisory team sometime involving experts beyond the awarding university.

\section{Literature Review}

Political attention increased for doctoral education with its inclusion in the Bologna Process in 2003 as the third level of higher education. It was stressed that the doctoral candidate should be regarded as a young professional instead of a student. Doctoral training was said to be the level at which bridges could be built between the European Higher Education Area (EHEA) and the European Research Area (ERA). In 2005 EUA adopted the Salzburg Principles and revised these in 2010. The Principles establish a framework for doctoral education in the Bologna Process based on research embedded in institutional strategies and the creation of structures to support doctoral training.

The eighth of the Salzburg Principles on doctoral training of the Bologna Process was «the promotion of innovative structures to meet the challenge of interdisciplinary training and the development of transferable skills» (EUA, 2006).

Jointly with the «Salzburg II Recommendations» of the European University Association (EUA) they have been «taken into account» in the Bucharest Ministerial Communiqué of the 48 Bologna signatory states in 2012 as important contributions for the further discussion of doctoral education in the third cycle ${ }^{2}$.

At the Ministerial Conference and Fourth Bologna Policy Forum in Yerevan (Armenia) on 14 and 15 May 2015 the ministers of education emphasised the need to strengthen the links between the European Higher Education Area (EHEA) and the European Research Area (ERA), in particular at the doctoral level.

\footnotetext{
2 Yerevan Communiqué (Mai 2015): http://bologna-yerevan2015.ehea.info/files/ YerevanCommuniqueFinal.pdf, (Accessed: October 2016).
} 
This paper aims at researching the European models and innovative participative practices of doctoral training in the political and practical contexts.

\section{Participative Approach in Doctoral Supervision}

The practical implementation of doctoral training has evolved considerably over the years and differs greatly between countries and individual institutions, due to a range of cultural, financial and socioeconomic factors. In Europe, procedures on admission, supervision, monitoring research progress and the thesis assessment have been implemented in a large number of institutions.

Yet there is no international norm on the duration and on the requirements. There is today no European model for doctoral training. There are two main trends in Europe, first the German/continental trend (with the doctoral training taking place after the Master) and the AngloSaxon tradition (with doctoral training placed Post-Bachelor after the Honours Degree). The critical issue is to determine whether the students are «research ready» to start a $\mathrm{PhD}$.

In 2011 the EU endorsed the EU Principles for Innovative Doctoral Training advocating that the new doctorate should combine excellence with interdisciplinary research, international exposure and intersectoral engagement. Based on expert advice, the European Commission has defined the seven Principles of Innovative Doctoral Training (Brussels, 2011) ${ }^{3}$ as follows:

\section{Research excellence}

Striving for excellent research is fundamental to all doctoral education and from this all other elements flow. Academic standards set via peer review procedures and research environments representing a critical mass are required. The new academic generation should be trained to become creative, critical and autonomous intellectual risk takers, pushing the boundaries of frontier research.

2. Attractive institutional environment

Doctoral candidates should find good working conditions to empower them to become independent researchers taking responsibility at an early stage for the scope, direction and progress of their project. These should include career development opportunities, in line with the European

${ }^{3}$ European Commission: Principles for Innovative Doctoral Training, Brussels (2011): http://ec.europa.eu/euraxess/pdf/research_policies/Principles_for_Innovative_Doctoral_Trainin g.pdf, (Accessed: October 2016) 
Charter for Researchers and the Code of Conduct for the Recruitment of Researchers.

\section{Quality assurance}

The accountability procedures must be established on the research base of doctoral education and for that reason, they should be developed separately from the quality assurance in the first and second cycle. The goal of quality assurance in doctoral education should be to enhance the quality of the research environment as well as promoting transparent and accountable procedures for topics such as admission, supervision, awarding the doctorate degree and career development. It is important to stress that this is not about the quality assurance of the $\mathrm{PhD}$ itself rather the process or life cycle, from recruitment to graduation.

\section{Interdisciplinary research options}

Doctoral training must be embedded in an open research environment and culture to ensure that any appropriate opportunities for crossfertilisation between disciplines can foster the necessary breadth and interdisciplinary approach.

\section{Transferable skills training}

The professional development training develops a range of skills that help $\mathrm{PhD}$ candidates to be more effective in their research but also to work on a broader range of skills that will be useful in their future lives and careers. These skills are often known as transferable skills.

«Transferable skills are skills learned in one context (for example research) that are useful in another (for example future employment whether that is in research, business etc). They enable subject- and research-related skills to be applied and developed effectively. Transferable skills may be acquired through training or through work

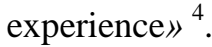

In the UK, VITAE has developed the Researcher Development Framework (RDF), which «articulates the knowledge, behaviours and attributes of successful researchers and encourages them to aspire to excellence through achieving higher levels of development». Skill development should be driven by the doctoral candidates themselves, in consultation with their supervisory team, to help them to mature and become independent both in their research and in their personal development. It is essential to ensure that enough researchers have the skills demanded by the knowledge based economy. Examples include

\footnotetext{
4 European Science Foundation 2010 «Research Careers in Europe Landscape and Horizons», ttp://www.esf.org/fileadmin/links/CEO/ResearchCareers_60p\%20A4_13Jan.pdf
} 
communication, teamwork, entrepreneurship, project management, IPR, ethics, standardisation etc.

\section{Exposure to industry and other relevant employment sectors}

The term «industry» is used in the widest sense, including all fields of future workplaces and public engagement, from industry to business, government, charities and cultural institutions (e.g. musea). This can include placements during research training; shared funding; involvement of non-academics from relevant industry in informing/delivering teaching and supervision; promoting financial contribution of the relevant industry to doctoral programmes; fostering alumni networks that can support the candidate (for example mentoring schemes) and the programme, and a wide array of people/technology/knowledge transfer activities.

\section{International networking}

Doctoral training should provide opportunities for international networking, i.e. through collaborative research, co-tutelle, dual and joint degrees. Mobility should be encouraged, be it through conferences, short research visits and secondments or longer stays abroad ${ }^{5}$ [2].

Generally speaking, internaolization in higher education is understood and interpreated in different ways that include several forms such as:

- «at home» (inspired by the «brain gain» model, its policy is to increase the institution's attractiveness through incoming mobility);

- «abroad» (based on unidirectional outgoing mobility policy sometimes implying «brain drain»);

- «cross-borders» (inspired by the model of «brain circulation» and «brain sharing», it is based on «share policy» and multilateral international and cross-sectoral mobility) seen as thevdelivery of education in cooperation with other countries through a varity of delivery modes (face to face, distance, e-learning, integrated didactic formula, etc.) and through different administrative arrangements (twinning, branch campuses, networked collaborative or joint programmes, etc.).

In all its forms, internationalization is an effective way of fostering quality in doctoral education and in research (less developed and younger countries or universities can learn a lot through international collaboration and can increase the overall quality in their institutions). However, it shold be clear that each diffent model of internationalization

\footnotetext{
${ }^{5}$ Bogle, David, et al.: Doctoral studies in Europe: excellence in researcher training. League of European Research Universities (2007), (Accessed: August 2016).
} 
offers different opportunities from the institutional, administrative and training perspective, wich must be precisely defined in order to avoid misunderstanding when using the same words to refer to very different institutional realities.

In the 2012 paper on ERA, the EU invites research stakeholder organisations, including universities, to provide structured doctoral training based on the Principles for Innovative Doctoral Training (EC, 2011) and invites Member States to support the setting up and running of structured innovative doctoral training programmes applying the Principles for Innovative Doctoral Training.

Individual universities are innovating in different ways and at different paces with doctoral training. Through their activities, several European university associations and other types of organisations and initiatives have compiled examples of good practices.

In 2010 and 2014 League of European Research Universities (LERU, 21 research intensive universities in 10 countries) produced two papers that compiled a range of practices and principles on doctoral education. LERU first published a position paper on the need for excellence in researcher training in Europe (LERU, 2007), followed by a second position paper presenting a vision for the future of doctoral training in Europe (LERU, 2012). The view of LERU is that doctoral training must prepare doctoral researchers to adapt outside academia and become the drivers of their own professional developments. To achieve this doctoral candidates, need a critical mass with a strong research environment in which they can thrive in research teams, with access to high quality research infrastructure.

The primary output is trained researchers who produce a thesis as documentary evidence of their original ideas and evidence to support them. An examination or defence demonstrates that the doctoral researcher can communicate and defend his/her own complex ideas and see his/her work within the context of the work of others. They also believe that a researcher should be trained in an environment that is international (research is international business), interdisciplinary (all research pushes disciplinary boundaries) and intersectoral (research must serve society; therefore it is important that its wider context is understood).

Every year through its doctoral summer schools LERU addresses a wide range of themes such as research integrity, plagiarism and fraud, access to transparent information in universities, principles of authorship and co-authorship, peer review, conflict of interest and data management. In previous years other topics were covered such as open science, open 
education and learning (including the issue of access, the definition of «data»), and doctoral school leadership. In 2015 the school focused on the knowledge economy and interactions with society, the media, government and science policy.

LERU's 2010 report, «Doctoral Studies beyond 2010», categorised the skill set developed during a $\mathrm{PhD}$ into intellectual, academic and technical, and personal and professional development skills (Table 1). These skills may be developed as part of the research project but are specifically addressed in formal training programmes ${ }^{6}$.

The following skills are sometimes also developed:

- the ability to lead other researchers

- the ability to teach and train others

- the ability to organise conferences and workshops.

The paper also documents good practice elements in doctoral training at LERU universities in four different categories:

1. Formal research training. Much professional development for researchers is now done through formal workshop-style professional development sessions to develop skills which can then be put to use in research and will be valuable in future careers.

2. Activities driven by doctoral candidates. A doctoral candidate's ability to drive initiatives is part of the process of becoming an independent researcher.

3. Career development. The section on provides examples of activities at LERU universities to promote awareness of both academic and non-academic careers that are open to doctoral graduates, highlighting in particular some areas that are less well known to our candidates.

4. The fourth category concepts and structures describes some of the innovative structures that LERU universities have developed for managing and promoting innovation in doctoral programmes, particularly for providing international and interdisciplinary exposure ${ }^{7}$.

\footnotetext{
${ }^{6}$ Bogle, David, et al.: Doctoral degrees beyond 2010: Training talented researchers for society. League of European Research Universities (2010): http://www.leru.org/files/publications/LERU_Doctoral_degrees_beyond_2010.pdf, (Accessed: August 2016).

${ }^{7}$ Bogle, David, et al.: Doctoral degrees beyond 2010: Training talented researchers for society. League of European Research Universities (2010): http://www.leru.org/files/publications/LERU_Doctoral_degrees_beyond_2010.pdf, (Accessed: August 2016).
} 
The Skill Set Developed During PhD

\begin{tabular}{|c|c|c|}
\hline $\begin{array}{l}\text { Intellectual skills, } \\
\text { which comprise the } \\
\text { ability to }\end{array}$ & $\begin{array}{l}\text { Academic and technical } \\
\text { skills, which comprise the } \\
\text { ability to }\end{array}$ & $\begin{array}{c}\text { Personal and } \\
\text { professional } \\
\text { management skills, } \\
\text { which comprise the } \\
\text { ability to }\end{array}$ \\
\hline $\begin{array}{l}\text { - think analytically } \\
\text { and synthetically; } \\
\text { - be creative, } \\
\text { inquisitive, and } \\
\text { original; } \\
\text { - take intellectual } \\
\text { risks; } \\
\text { - deploy specific } \\
\text { technical research } \\
\text { related tools and } \\
\text { techniques. }\end{array}$ & $\begin{array}{l}\text { - understand, test and } \\
\text { advance complex theories or } \\
\text { hypotheses and to deploy } \\
\text { sophisticated concepts, } \\
\text { methodologies and tools in } \\
\text { the chosen subject to a very } \\
\text { high level; } \\
\text { - be able to identify issues } \\
\text { and translate them into } \\
\text { questions amenable to } \\
\text { scholarly enquiry; } \\
\text { - successfully pursue } \\
\text { original research in the } \\
\text { chosen field; } \\
\text { an objective manner based } \\
\text { an verifiable evidence; } \\
\text { on apply highest standards } \\
\text { of rigour in the proof of } \\
\text { ideas; } \\
\text { - manage a high degree of } \\
\text { uncertainty both in method } \\
\text { and in outcomes; } \\
\text { - develop and demonstrate } \\
\text { academic credibility and } \\
\text { become recognised as a } \\
\text { member of an international } \\
\text { scholarly community; } \\
\text { o understand the workings } \\
\text { of a specific high level } \\
\text { research-intensive } \\
\text { environment; } \\
\text { - transfer new knowledge } \\
\text { to scholarly communities and } \\
\text { communicate it to society; } \\
\text { e work according to } \\
\text { ethical principles; } \\
\text { interdisciplinarity setting or } \\
\text { on an interdisciplinary topic. }\end{array}$ & $\begin{array}{l}\text { - persist in achieving } \\
\text { long terms goals; } \\
\text { - manage projects with } \\
\text { uncertain outcomes in } \\
\text { diverse settings and } \\
\text { organisations; } \\
\text { - take a project through } \\
\text { all its stages: from } \\
\text { developing the original } \\
\text { idea, to developing a } \\
\text { plan, garnering the } \\
\text { evidence, and } \\
\text { communicating the } \\
\text { results and their } \\
\text { significance; } \\
\text { - be self-motivated and } \\
\text { autonomous; } \\
\text { - work to achieve results } \\
\text { with minimum } \\
\text { supervision; } \\
\text { - be flexible and } \\
\text { adaptable in approaching } \\
\text { complex and uncertain } \\
\text { problems; } \\
\text { - communicate very } \\
\text { complex concepts; } \\
\text { - network internationally; } \\
\text { - work in a team; } \\
\text { - speak and present } \\
\text { effectively in public. }\end{array}$ \\
\hline
\end{tabular}


The key point is that universities should, while keeping in mind the principles of excellence in doctoral training proposed in LERU and the innovative doctoral training principles developed by the EC, provide a doctoral training system and mechanisms which include well-rounded, versatile and personalisable professional development opportunities and programmes, enabling doctoral researchers to take control of, track and self-assess their development with the necessary guidance from supervisory teams, so that, by the time of graduation, they are able to seek out those job opportunities that are best suited to their talents, expertise and skills.

\section{CONCLUSSIONS}

From the research reviewed, it is possible to draw several conclusions. There is evidence to suggest that in the context of realization the EU politic connected with the third cycle of higher education, doctoral training, the main tasks and tendencies are the follows:

- Keep in mind the principles of excellence in doctoral training proposed in LERU (2010) and the innovative doctoral training principles developed by the EC (2011);

- Provide a well-rounded professional development programme which enables doctoral candidates to assemble an individual training programme tailored to their needs;

- Devise systems that allow candidates to take control of, track and self-assess their own development, with guidance from supervisory teams;

- Promote innovation and sharing of best practice in skills training within the institution and also with other Universities nationally and internationally;

- Use national and international networks and fora, where appropriate, to share skills development provision;

- Ensure that their doctoral training structures and programmes are regularly refreshed in order for them to remain innovative and responsive to change;

- Engage with employers to ensure that professional development of researchers is fit for both academic and non-academic employers. 


\section{SUMMARY}

The doctorate is considered as one of the driving forces to generate economic growth and support positive developments in society, and in the knowledge economy. Therefore, information about the EU doctoral training tendencies can be useful for providing modernization of the national higher education system, the third, $\mathrm{PhD}$ level in particular. This paper describes the European models and innovative practices of doctoral training in the political and practical contexts.

\section{REFERENCES}

1. Bogle, David, et al.: Doctoral degrees beyond 2010: Training talented researchers for society. League of European Research Universities (2010):

http://www.leru.org/files/publications/ LERU_Doctoral_degrees_beyond_2010.pdf, (Accessed: August 2016).

2. Bogle, David, et al.: Doctoral studies in Europe: excellence in researcher training. League of European Research Universities (2007), (Accessed: August 2016).

3. Bogle. David, Maes Katrien: Good Practice Elements in Doctoral Training. Follow-on paper to Doctoral degrees beyond 2010: Training talented researchers for society. League of European Research Universities (2014):

http://www.leru.org/files/publications/ LERU_AP_15_Good_practice_elements_in_doctoral_training_2014.pdf, (Accessed: August 2016).

4. Bucharest Ministerial Conference (2012): "Mobility for Better Learning. Mobility strategy 2020 for the European Higher Education Area (EHEA)". http://www.ehea.info/cid101043/ministerial-conferencebucharest-2012.html

5. Communiqué, Berlin: Realising the European Higher Education Area. Communique of the Conference of Ministers responsible for Higher Education in Berlin on 19 September 2003. (2003): http://www.ond.vlaanderen.be/hogeronderwijs/bologna/documents/mdc/ berlin_communique1.pdf, (Accessed: October 2016)

6. European Commission: Europe 2020 - A European Strategy for smart, sustainable and inclusive growth. European Commission, COM (3.3. 2010) (2010).

7. European Commission: Principles for Innovative Doctoral Training, Brussels (2011): http://ec.europa.eu/euraxess/pdf/ research_policies/Principles_for_Innovative_Doctoral_Training.pdf, (Accessed: October 2016) 
8. European Science Foundation 2010 «Research Careers in Europe Landscape and Horizons», http://www.esf.org/fileadmin/links/ CEO/ResearchCareers_60p\%20A4_13Jan.pdf

9. Yerevan Communiqué (Mai 2015): http://bolognayerevan2015.ehea.info/files/YerevanCommuniqueFinal.pdf, (Accessed: October 2016).

\section{Information about the authors:} Boychuk P. M., Candidate of Pedagogical Sciences, Associate Professor, Rector, Municipal Higher Educational Institution "Lutsk Pedagogical College" of the Volyn Regional Council 36 Voli ave., Lutsk, Volyn region, 43010, Ukraine

Fast O. L.,

Candidate of Pedagogical Sciences, Associate Professor, Vise-rector on Research, Teaching and International Relations, Municipal Higher Educational Institution "Lutsk Pedagogical College" of the Volyn Regional Council 36 Voli ave., Lutsk, Volyn region, 43010, Ukraine

Martyniuk A. P., Candidate of Pedagogical Sciences, Associate Professor, Head of the Department of Ukrainian and Foreign Philology, Lutsk National Technical University 75 Lvivska str., Lutsk, Volyn region, 43000, Ukraine 